\title{
Nauczanie języków obcych w erze post-metodycznej: Glówne założenia i kierunki
}

\author{
Maria Jodłowiec
}

Uniwersytet Jagielloński w Krakowie maria.jodlowiec@uj.edu.pl

\section{Anna Niżegorodcew}

Uniwersytet Jagielloński w Krakowie anna.nizegorodcew@uj.edu.pl

\begin{abstract}
Streszczenie
Bezprecedensowe tempo zmian we wspótczesnym świecie $i$ wymagania, które stawia nauczycielom nowoczesna szkoła, z jednej strony w sposób znaczacy wpływaja na dydaktyke języków obcych, z drugiej zaś na przygotowanie nauczycieli języków obcych do zawodu. W chwili obecnej glottodydaktyka wkroczyła $w$ faze post-metodyczna, w nauczaniu/uczeniu sie języków podkreśla się perspektywę ekologizmu, a w kształceniu nauczycieli kładzie się nacisk na rozwój autonomii, samodzielności $w$ generowaniu wiedzy $i$ zdobywaniu nowych umiejętności oraz otwartości na zmienność i dynamike rzeczywistości. W niniejszym artykule pragniemy wyjaśnić sedno tej reorientacji $i$ zarysować główne zasady, $z$ których owe przekształcenia wynikaja. Opisując krótko post-metodyczny model Kumaravadivelu (2003, 2006b), kreślimy ramy post-nowoczesnej glottodydaktyki. Wskazujemy jednocześnie, jak zmienność i nieprzewidywalność wspótczesnego świata przesądza o tym, że nauczyciel języka obcego, właściwie przygotowany do wykonywania swego zawodu, to przede wszystkim osoba otwarta, gotowa do uczenia się przez całe życie i do budowania teorii na podstawie praktyki, a równocześnie wykorzystujaca praktykę by teorię umiejętnie modyfikować. To kreatywny profesjonalista nastawiony na rozpoznawanie i rozwiąywanie problemów.
\end{abstract}

Stowa kluczowe: dydaktyka nauczania języka obcego, model post-metodyczny, kontekst ekologiczny, rola nauczyciela

Abstract

Teaching Foreign Languages in the Post-Method Era; Leading Assumptions and Tendencies 
The unprecedented speed of change in the world today and the demands that modern school places on the teacher, on the one hand, affect foreign/second language didactics, and on the other, influence language teacher programmes. In the 21st century L2 didactics appears to have entered a post-method era education, informed by language ecologism, and marked by emphasis on teacher autonomy. The teacher is no longer supposed to be primarily the knower; instead he or she must be an individual capable of generating new knowledge and developing skills necessary to deal with the unpredictable and changeable reality. The paper attempts to elucidate the nature of these new tendencies and presents the major principles of L2 teaching and learning that follow from them. Kumaravidelu's (2003, 2006b) post-method model is focused on as the epitome of post-modern L2 instruction. It is argued that it lays foundation for open-ended teacher education, the major goal of which is to create in future language teachers the attitudes and abilities indispensable to a self-exploring and self-directed practitioner.

Keywords: foreign language teaching, post-method model, language ecologism, teacher education.

\section{Nauczanie post-metodyczne: geneza}

Już pod koniec lat 80 -ych ub. stulecia odezwały się głosy badaczy wieszczących koniec ery metod w dydaktyce języków obcych (np. Allwright 1991; Pennycook 1989; Prabhu 1990). W odróżnieniu od wiodących nurtów w teorii nauczania języków w wieku XX, podporządkowanych poszukiwaniu optymalnej czy „najlepszej” metody, u progu nowego tysiąclecia wizja stworzenia metody-panaceum stała się nie tylko nierealna, ale wręcz niezgodna z post-nowoczesną koncepcją nauczania języków obcych. Z tej perspektywy, próby formułowania i udoskonalania zestawu procedur pedagogicznych, wywodzących się z teorii psychologicznych, językoznawczych, psycholingwistycznych czy socjolingwistycznych i zdefiniowanych jako metoda, czy to audiolingwalna, kognitywna, reagowania całym ciałem, czy sugestopedia, okazały się być poszukiwaniem bezcelowym, a ich miejsce zajęła dydaktyka post-metodyczna.

Radykalny odwrót od metody, jako zestawu reguł dydaktycznych, które stanowiłyby podbudowę teoretyczną dla nauczania języka, zgodną z najnowszymi zdobyczami nauk językoznawczych i społecznych, i które w sposób uporządkowany, adekwatnie umotywowany wytyczałyby techniki pracy $\mathrm{z}$ uczniem, ma wiele powodów. Wymienimy tu tylko najważniejsze. Po pierwsze, zwrot ten ma swoje źródło w rozczarowaniu, jakie towarzyszyło wdrażaniu w praktyce pedagogicznej coraz to nowych metod, które obiecywały zazwyczaj dużo lepsze efekty niż te osiągane przez uczniów nauczanych w sposób bardziej klasyczny. Badania porównujące efektywność nowych i tradycyjnych metod ujawniły nie tylko, że nie można przesądzić o lepszych rezultatach nauczania osiąganych dzięki bardziej nowoczesnym 
metodom (jak pokazało choćby porównanie metody audiolingwalnej i „tradycyjnego” nauczania w Stanach Zjednoczonych pod koniec lat 60-tych, Nunan 1992: 92-3), ale wskazały, że sama idea porównania metod skazana jest z góry na niepowodzenie. Nie można bowiem zakładać, że różni nauczyciele, o specyficznych cechach osobowościowych, z idiosynkratycznym balastem doświadczeń, funkcjonujący w odmiennych kontekstach dydaktycznych, którzy zdecydują się na wykorzystanie w swym nauczaniu danej metody, będą de facto uczyć w taki sam (czy przynajmniej w bardzo podobny) sposób. Na dodatek, teoretyczne założenia metod nauczania i ich realizacja w praktyce mogą znacznie się od siebie różnić, co podważa koncepcję metody jako takiej. Skoro wcielenie w życie czyni z jednorodnego, spójnego i określonego systemu postulatów dydaktycznych zestaw reguł nauczania różnorodnie wykorzystywanych w różnych sytuacjach pedagogicznych, metoda przestaje po prostu być metodą.

Po drugie, zglobalizowany świat, w którym podróżowanie na dużą skalę, praca w wielonarodowych korporacjach, łatwość komunikacji pomiędzy przedstawicielami narodów z różnych stron kuli ziemskiej i procesy migracyjne są codziennością, tworzy nowy kontekst i wyznacza inne cele dla uczenia się języków obcych. Należy przy tym zwrócić uwagę na uprzywilejowany status języka angielskiego jako lingua franca: opanowanie tego języka na poziomie komunikacyjnym stało się jednym z ważnych elementów nie tylko kompetencji zawodowej, ale wręcz przygotowania do życia we współczesnym świecie - trudno korzystać w pełni z możliwości, które daje człowiekowi dzisiejsza rzeczywistość bez znajomości tego języka. W sposób istotny wpływa to na motywację uczniów, ale też na ich oczekiwania i aspiracje (niekoniecznie bardzo wygórowane, np. w odniesieniu do opanowania gramatyki angielskiej), co znajduje swe odzwierciedlenie w materiałach dydaktycznych, które nie mogą nie uwzględniać zasobów elektronicznych, źródeł internetowych, pomocy multimedialnych itp., a w konsekwencji, na przygotowanie nauczycieli do zawodu. Trudno przy tym przewidzieć, jakie dalsze możliwości da dydaktykowi języka postęp technologiczny $w$ najbliższej przyszłości, czego naturalnym następstwem wydaje się fakt, że konkretne metody nauczania języka ustępują miejsca dydaktyce dynamicznej, którą umie tworzyć - a nie po prostu odtwarzać - nauczyciel otwarty na świat i to, co świat ten oferuje, gotowy do stawania czoła stale nowym wyzwaniom i umiejący szukać rozwiązań dla nieustanie nowych problemów (por. Cook 2000: 181).

Poniekąd z tego „nowego” kontekstu, w jakim uczymy się języków obcych, wynika trzeci ważny powód odejścia od koncentrowania się na metodach nauczania języków obcych we współczesnej glottodydaktyce. Chodzi o świadomość złożoności procesu dydaktycznego oraz 
istotnego, żeby nie powiedzieć zasadniczego, wpływu nauczyciela na osiągnięcia ucznia. Po długo utrzymującej się tendencji skupiania się na uczniu i uczynienia zeń centrum mikrokosmosu dydaktycznego, nadszedł czas skierowania uwagi na osobę nauczyciela (Jodłowiec 2013). Niewątpliwie tylko nauczyciel dobrze przygotowany do swej roli, umiejący właściwie zanalizować sytuację pedagogiczną, w której się znalazł, otwarty na zdobywanie nowej wiedzy i umiejętności oraz gotowy do generowania nowatorskich rozwiązań dydaktycznych poradzi sobie $\mathrm{z}$ nieprzewidywalnym i dynamicznie zmieniającym się kontekstem klasowym (por. Kwiatkowska 1997).

W podsumowaniu warto podkreślić, że z punktu widzenia wyzwań, stojących w obecnej chwili przed nauczycielami języka obcego, metoda ma nie tyle ograniczony co ograniczający wpływ na proces nauczania i uczenia się języków (Kumaravadivelu 2006a: 67).

\section{Dydaktyka post-metodyczna: główne zalożenia}

Jaki jest program dydaktyki post-metodycznej? Za prekursora idei post-metodycznych w dydaktyce języków obcych można uznać Sterna (1992; por. Kumaravadivelu 2006a). Już 25 lat temu uwypuklał on rolę wiedzy nauczyciela w kontekście dokonywania rozmaitych wyborów, zarówno na poziomie tworzenia i wdrażania programu języka obcego (a więc tego, co Stern rozumie pod pojęciem strategii), jak i decyzji dokonywanych w klasie (czyli technik świadomie wybranych do realizacji poszczególnych celów dydaktycznych; Stern 1992).

Najbardziej znanym (i uznanym) modelem post-metodycznym jest model makrostrategii zaproponowany przez Kumaravadivelu (2001, 2003, 2006a, 2006b). Posłużymy się nim, aby wskazać na istotne elementy kształcenia nauczycieli w erze post-metodycznej, a równocześnie scharakteryzować post-metodyczne nauczanie języków obcych. Podstawą systemu kształcenia nauczycieli, który stworzył ten znany amerykański badacz, jest - zakorzeniona w podejściu postmodernistycznym, jak wskazano powyżej - przesłanka, że istnieje zbyt duża nieprzewidywalność parametrów określających sytuację pedagogiczną, w której będzie musiał działać nauczyciel języka obcego (jeśli chodzi o cele, środki, przedmiot, czy narzędzia nauczania), by można go było wyposażyć w wiedzę i umiejętności potrzebne do podjęcia skutecznych działań dydaktycznych. Rola nauczyciela, jak przekonuje Kumaravadivelu (2003: 8-10), nie może być sprowadzona do roli technika, którego celem jest wykorzystanie w praktyce zdobytych w trakcie kształcenia umiejętności. Nauczyciel musi być przede wszystkim refleksyjnym praktykiem, zdolnym do własnych, pogłębionych analiz, na podstawie których będzie mógł wymyślić rozwiązania problemów, często bardzo swoistych i 
specyficznych, na które napotka w pracy z uczniami. Stąd kształcenie nauczycieli musi być ukierunkowane na kształtowanie postaw, umiejętności i podnoszenie świadomości adeptów zawodu tak, by byli oni przygotowani na ustawiczne samokształcenie i zdolni do przystosowania swojego warsztatu pedagogicznego do zmiennej i dynamicznej rzeczywistości.

Model Kumaravadivelu (2003, 2006b) opiera się na trzech zasadach: na zasadzie specyficzności (particularity), praktyczności (practicality) i perspektywiczności (possibility). Zgodnie z pierwszą z nich, nauczanie w ogóle, a nauczanie języka obcego w szczególności, musi być zawsze odpowiednio dostosowane do specyfiki kontekstu, w którym ma miejsce. Zasada specyficzności jest więc antytezą do przekonania, że można jednoznacznie zdefiniować zbiór celów dydaktycznych, a następnie wyznaczyć drogę ich realizacji poprzez określenie zestawu reguł i procedur pedagogicznych, jak ma to miejsce w obrębie konkretnych metod nauczania (Kumaravadivelu 2001: 538). Aby mieć sens i służyć właściwie zarówno nauczycielom, jak i uczniom, stosowane zasady glottodydaktyczne muszą brać pod uwagę specyficzne uwarunkowania lokalne. To właśnie zignorowanie miejscowej tradycji edukacyjnej, swoistych warunków kulturowych, oczekiwań pokładanych w nauce języka obcego, itp. miało przesądzić o niepowodzeniu zastosowania podejścia komunikacyjnego w nauczaniu języków obcych w krajach takich, jak Republika Południowej Afryki, Pakistan, Japonia, Tajlandia czy Chiny (Kumaravadivelu 2006a: 63-4, 2006b: 43), żeby nie wspomnieć o Polsce i innych krajach europejskich. Kształtowanie postaw uwrażliwienia na kontekst, zarówno ten bardzo szeroki, społeczno-polityczny i kulturowy, jak i ten wąski, odnoszący się do konkretnej sytuacji, w jakiej odbywa się kurs języka, jest istotnym warunkiem dobrego przygotowania nauczyciela do pracy dydaktycznej.

Zasada praktyczności w dydaktyce post-metodycznej określa relację pomiędzy teorią i praktyką w działaniach pedagogicznych, wskazując na ich wzajemną nierozerwalność. Zgodnie z postulatami Kumaravadivelu (2003: 541), nauczyciel powinien tworzyć teorię na podstawie praktyki i opierać praktykę na teorii (,theorize from their practice and practice what they theorize"). Oznacza to, że pożyteczna teoria to teoria, do której dochodzi się przez praktykę. Nauczyciel wyposażony w odpowiednie narzędzia badawcze, posługujący się sprawnie strategiami refleksyjnego praktyka, powinien umieć identyfikować i analizować problemy dydaktyczne, zbierać potrzebne dane, rozważyć stosowne rozwiązania, wybrać najlepsze $\mathrm{z}$ nich i zastosować je w praktyce, by wreszcie poddać rezultaty swych działań odpowiedniej analizie krytycznej (por. Lankiewicz 2015). Nauczyciel, który myśli w działaniu i nad działaniem (por. Jodłowiec 2013; van Lier 2007) ma więc pełnić rolę badacza 
(Zawadzka, 2004) przez podejmowanie badania w działaniu (,action research”), dzięki czemu będzie mógł świadomie kształtować kontekst klasowy. Teoria nie jest więc zbiorem wiedzy, którą praktyk ma umiejętnie stosować w pracy z uczniami, gdyż takiej roli nie może ona pełnić, ale zasobem, z którego czerpie wymyślając nowe sposoby pracy z uczniami i generując rozwiązania problemów, które - dzięki posiadanej wiedzy teoretycznej - jest w stanie właściwie rozpoznać.

Zasada perspektywiczności zakłada, że sytuacja dydaktyczna opiera się na kontakcie osób spełniających ustalone role społeczne, wyznających pewien system wartości, posiadających określoną tożsamość i funkcjonujących w ramach jakiegoś systemu społeczno-politycznego. Rozwijanie kompetencji w języku drugim czy obcym wpływa na tożsamość społecznopolityczną jednostki i jej świadomość, a dydaktyka języków obcych nie może ignorować tego faktu i powinna programowo wspierać właściwy rozwój ucznia (Kumaravadivelu 2001: 542_ 4).

Trzy zasady, krótko omówione powyżej, stanowią ramy post-metodycznej dydaktyki, która ma stanowić alternatywę dla dydaktyki opartej na metodach i wyznaczać kierunek dalszego rozwoju glottodydaktyki w naszych czasach. Trudno upatrywać w tych postulatach jakichś rewolucyjnych zmian: nie zwiastują one nadejścia nowego paradygmatu, a jedynie sankcjonują eklektyczne podejście do nauczania-uczenia się języka. Nauczyciel ma być przygotowany do stałego rozwoju i ulepszania swojego profesjonalnego warsztatu, aby móc nieustannie rozwijać - niezwiązane z konkretną teorią czy metodą - strategie działania pedagogicznego, optymalnie służące do osiągania celów pedagogicznych, które przed nim stoją.

Nowatorstwo tego ujęcia niewątpliwie polega na ,urealnieniu” postrzegania, czym jest uczenie się języka: nie jest to proces linearny, który wiąże się ze stabilnym i niezakłóconym wzrostem; nie jest to też proces podlegający ściśle normatywnym zasadom (por. Kramsch 2002). Z dynamicznej koncepcji przyswajania języka jasno wynika, że rozwój umiejętności posługiwania się językiem drugim/obcym jest rozpatrywany jako proces holistyczny, odbywający się jednocześnie na wielu płaszczyznach i charakteryzujący się dynamizmem (Järvinen 2009). Tego typu podejście do edukacji językowej określa się mianem ekologicznego. Jak stwierdza Kramsch (2008), podejście ekologiczne w glottodydaktyce wspiera pięć głównych filarów. Są to :

1. relatywizacja pojęcia ja i pojęcia inny (ja ma zawierać w sobie odniesienie do innych ludzi, a sytuacje komunikacyjne mają być rozumiane jako obejmujące „wiele głosów”); 
2. wszechobecny emergentyzm (formy językowe, przekazywane znaczenia, wynik nauczania itp. mają wyłaniać się w rezultacie interakcji wielu zmiennych);

3. niedomykalność (procesu komunikowania się nigdy nie można uznać za skończony: jest częścią nieskończonej sieci przeszłych i przyszłych konwersacji, prezentacji i innych sposobów przekazywania treści);

4. wielość skali czasowych (wyrażone za pomocą języka znaczenia funkcjonują w obrębie rozmaitych skali czasu, planów rzeczywistych i fikcyjnych, a ich wynik jest często nieprzewidywalny lub niezamierzony);

5. fraktalność (użycie języka, interakcje międzyludzkie, akty komunikacyjne itp. mają cechy obiektów fraktalnych, czyli takich w których części podobne są do całości)

(Kramsch 2008: 391-393)

Przyjęcie takiej immanentnie „otwartej” perspektywy w dydaktyce języka jest podstawą określonej filozofii nauczania języka drugiego/obcego i wynikających $\mathrm{z}$ niej praktyk lekcyjnych.

\section{Kierunki post-nowoczesnej dydaktyki}

Dydaktyka post-metodyczna, podważając zasadność funkcjonowania metody jako jednorodnego systemu procedur pedagogicznych, związanych $\mathrm{z}$ określonym modelem teoretycznym, w pełni współgra z perspektywą ekologiczną w dydaktyce, krótko nakreśloną powyżej. Ustawiczne poszukiwanie nowych rozwiązań, otwartość na zmienność i nieprzewidywalność, kompleksowe podejście do zjawisk językowych i procesów zachodzących w klasie lekcyjnej - oto najważniejsze postulaty post-nowoczesnego nauczania. Na gruncie praktyki glottodydaktycznej realizowane są one m.in. przez:

- nauczanie i uczenie się zadaniowe, obejmujące rozwijanie autonomii uczniów (TaskBased Language Teaching and Learning),

- nauczanie języków obcych zintegrowane z nauczaniem i uczeniem się treści (Content and Language-Integrated Teaching and Learning),

- nauczanie języków obcych zintegrowane z nauczaniem kulturowym oraz rozwijaniem kompetencji interkulturowej,

- nauczanie języków obcych na odległość,

- wykorzystanie narzędzi elektronicznych i mulitimedialnych w pracy z uczniami, 
- ocenianie rozwoju językowego uczniów w oparciu o Europejski system opisu kształcenia językowego (ESOKJ) wraz z innymi kryteriami oceny alternatywnej (w tym samooceny).

Można założyć, że we wszystkich powyższych kierunkach poszukiwań, nauczyciele języków obcych dostosowują teorię do praktyki; wręcz trudno sobie wyobrazić nauczanie, które nie brałoby pod uwagę specyfiki kontekstu, w którym działają nauczyciel i uczniowie. Oczywiście praktyka nieuchronnie wpływa na kształt teorii nauczania, ale znowu ta świadomość wydaje się towarzyszyć teoretykom i praktykom nauczania „od zawsze”.

Należy również zauważyć, że wymienione powyżej kierunki rozwoju nowoczesnej - a ściśle rzecz biorąc post-nowoczesnej - dydaktyki języków obcych spełniają zasady specyficzności, praktyczności i perspektywiczności w tym sensie, że czerpią one z lokalnych i interkulturowych kontekstów (por. Niżegorodcew 2009) oraz sprowadzają nauczanie i uczenie się, a także ocenianie znajomości języków obcych, do dających się określić ram: pewnego zadania, projektu, czy też ukierunkowanej na realny cel użytkowy pracy ucznia. Obok funkcji poznawczych, wszystkie kładą nacisk na szeroko pojęty rozwój osobisty, a więc obejmują swym zasięgiem nie tylko sprawności kognitywne, ale formację emocjonalną i kształtowanie osobowości, postaw, systemu wartości itp. Procesy te mają objąć nie tylko ucznia, ale i nauczyciela, który - świadom konieczności kształcenia się przez całe życie i traktujący zmianę jako oczywisty element współczesności - gotowy jest udoskonalać swój warsztat, modyfikować wypracowane wcześniej procedury dydaktyczne i wykorzystywać wciąż nowe materiały oraz pomoce na lekcji.

Czy te wyzwania nie spowodują wcześniejszego wypalenia zawodowego nauczycieli języka? Wbrew obiegowym opiniom, stawanie przed coraz nowymi problemami, mobilizacja poznawcza, aktywność intelektualna i odejście od powtarzania bez przerwy tych samych czynności, jest najlepszym środkiem chroniącym nauczyciela przed wypaleniem zawodowym. Zatem podążanie za nowymi kierunkami w pedagogice i glottodydaktyce, i wprowadzanie w życie nowych koncepcji w nauczaniu i uczeniu się języków obcych nie powinno być postrzegane jako jeszcze jeden balast na barkach nauczyciela, ale jako szansa na wyjście poza utarte schematy i uruchomienie kreatywności. Nic nie odbiera tak energii jak pasywność i nieustanne używanie tych samych tekstów, ćwiczeń, testów itd.

Niewątpliwie podjęcie tych wyzwań wymaga odpowiedniego nastawienia. Wydaje się więc, że programy kształcenia nauczycieli powinny zadbać przede wszystkim o kreowanie właściwych postaw i przygotować adeptów do pogłębionej refleksji, bo to da im adekwatną 
podbudowę do pracy z uczniami, którzy dziś przychodzą do szkoły z przekłutymi brwiami i tabletami, ale jak będą wyglądali jutro i z czym pojawią się w szkole, tego jeszcze nie wiemy.

\section{Informacje dodatkowe}

Niniejszy tekst jest uzupełnioną i w dużej części zmienioną wersją artykułu pt. „W stronę post-nowoczesnej dydaktyki języków obcych" w tomie W stronę nowoczesnej dydaktyki języków obcych pod redakcją Marii Jodłowiec i Anny Niżegorodcew, Język a komunikacja 22, Kraków: Tertium; 15-21.

\section{Bibliografia}

Allwright, Richard (1991) „The Death of the Method?” Working Papers, Lancaster University 10 ; bs.

Cook, Guy (2000) Language Play, Language Learning. Oxford: Oxford University Press. Järvinen, Heini-Marja (2009) „What has ecology to do with CLIL? An Ecological Approach in Content and Language Integrated Learning.” [W:] David Marsh D., Peter Mehisto, Dieter Wolff, Rosa Aliaga, Tuula Asikainen, María Jesús Frigols-Martin, Sue Hughes, Gisella Lange (red.). CLIL Practice: Perspectives from the Field. Jyvaskyla: University of Jyvaskyla; 164-171.

Jodłowiec, Maria (2013) „Language Teacher Education as a Complex Adaptive System”. [W:] Elżbieta Mańczak-Wohlfeld, Maria Jodłowiec (red.) Exploring the Microcosm and Macrocosm of Language Teaching and Learning. Kraków: Jagiellonian University Press; 197-206.

Kramsch, Claire (2002) „Standard, Norm and Variability in Language Learning: A View from Foreign Language Learning Research”. [W:] Susan Gass, Kathleen Bardovi-Harlig, Sally Magnan Pierce, Joel Walz (red.) Pedagogical Norms for Second and Foreign Language Learning and Teaching: Studies in Honour of Albert Valdman. Amsterdam: John Benjamins; 59-79.

Kramsch, Claire (2008) „Ecological Perspective in Foreign Language Education.” Language Teaching 41(3); 389-408.

Kwiatkowska, Henryka (1997) Edukacja nauczycieli: konteksty-kategorie-praktyki, Warszawa: Instytut Badań Edukacyjnych. 
Kumaravadivelu, Bala (2001) „Toward a Postmethod Pedagogy”. TESOL Quarterly 35; 537560.

Kumaravadivelu, Bala (2003) Beyond Methods: Macrostrategies for Language Teaching. New Haven: Yale University Press.

Kumaravadivelu, Bala (2006a) „TESOL methods: changing tracks, challenging trends”. TESOL Quarterly 40; 59-81.

Kumaravadivelu, Bala (2006b) Understanding Language Teaching: From Method to Postmethod. London: Lawrence Erlbaum.

Lankiewicz, Hadrian (2015) Teacher Language Awareness in the Ecological perspective: A Collaborative Inquiry Based on Languaging. Gdańsk: Wydawnictwo Uniwersytetu Gdańskiego.

Niżegorodcew, Anna (2009) „Conceptual and Research Aspects of Student-centred Intercultural Projects". Formazione \& Insegnamento 7(3); 175-180.

Nunan, David (1992) Research Methods in Language Learning, Cambridge: Cambridge University Press.

Pennycook, Alastair (1989) „The concept of method, interested knowledge, and the politics of language", TESOL Quarterly 23; 589-618.

Prabhu, N.S. (1990) „There is no best method-why?” TESOL Quarterly 24; 161-176.

Stern, Hans (1992) Issues and Options in Language Teaching. Oxford: Oxford University Press.

van Lier, Leo (2007) „Action-based Teaching, Autonomy and Identity”. Innovations in Language Learning and Teaching. 1(1); 46-65.

Zawadzka, Elżbieta (2004) Nauczyciele języków obcych $w$ dobie przemian. Kraków: Impuls. 